\title{
The Genetics of Bile Acid Degradation in Pseudomonas spp.: Location and Cloning of Catabolic Genes
}

\author{
By RAYMOND A. LEPPIK† \\ CSIRO Division of Food Research, Meat Research Laboratory, PO Box 12, Cannon Hill, \\ Queensland 4170, Australia
}

(Received 30 June 1988; revised 7 March 1989; accepted 24 March 1989)

Four Pseudomonas spp. capable of utilizing bile acids as sole carbon source were examined for the presence of plasmids. One plasmid was found in Pseudomonas sp. RAL8, but no plasmids could be detected in the other three strains. Mitomycin C curing of RAL8 did not affect the ability of the strain to grow on bile acids. This suggested that the genetic information for bile acid catabolism in all four strains was chromosomally located. To isolate bile acid catabolic genes, DNA from RAL8 was partially digested with Sau3A, then the DNA fragments cloned into the broad-host-range cosmid vector pMMB33. The resulting gene bank was screened by plate-mating with two stable RAL8 mutants. Four of the gene bank clones were found to give a positive complementation with one or both mutants. Examination of the plasmids in the four clones revealed that they were unstable, but detailed mapping enabled a $52 \mathrm{~kb}$ restriction map to be derived. Further complementation work showed that two of the bile acid catabolic genes are located close together on the map, and may be contiguous.

\section{INTRODUCTION}

Over the past four decades, the microbial catabolism of the bile acids has been extensively studied by a number of workers. This has resulted in the elucidation of two main degradative pathways, utilized respectively by the Gram-positive and the Gram-negative micro-organisms examined (Leppik \& Sinden 1987, and references therein). In more recent years, transposon mutagenesis studies on some of the Pseudomonas spp. have commenced, and a number of Tn5 transposon mutants affected in bile acid catabolism have been isolated and characterized [Ide $e t$ al., 1986; Leppik \& Sinden, 1987; Leppik, 1989 (accompanying paper); Park et al., 1988].

Very little, however, is known about the genetics of bile acid degradation. In the only publication to date in this area, Tenneson et al. (1979) examined 37 isolates, and all were found to be capable of losing their ability to utilize bile acids, either as a result of growth on nutrient agar, or as a result of treatment with mitomycin $C$. This was interpreted as indicating that the bile acid degradative genes were plasmid-borne. The only other relevant paper was published by Coleman et al. (1987), who reported the cloning of the bile acid 7-dehydroxylase gene from a Eubacterium sp. Whilst this gene would not appear to be involved in bile acid degradation, it is the first report of the cloning of any gene involved in bile acid metabolism.

In order to gain an understanding of the genetics of bile acid catabolism, studies aimed at the cloning and characterization of the genes involved were commenced. The first results from this research are presented in this paper.

\section{METHODS}

Bacterial strains, plasmids, and media. The bacterial strains and plasmids are listed in Tables 1 and 2 . The media used is as previously described (Leppik \& Sinden, 1987), except that rifampicin was used at $25 \mu \mathrm{g} \mathrm{ml}^{-1}$.

† Present address: Merrell Dow Research Institute, 16 rue d'Ankara, 67084 Strasbourg Cedex, France. 
Table 1. Bacterial strains used

Strain

\author{
E. coli LE392 \\ E. coli RAL3 \\ E. coli $\mathrm{S} 17.1$
}

P. putida PP1-2

$P$. putida RAL34

Pseudomonas sp. RALl

Pseudomonas sp. RAL8

Pseudomonas sp. RAL8.14

Pseudomonas sp. RAL8.17

Pseudomonas sp. RAL20

Pseudomonas sp. RAL91
Relevant characteristics*

$h s d R 514\left(r^{-} m^{+}\right)$supE44 supF58 metBI

$\operatorname{trpR55} \lambda^{-}$

nal ${ }^{r}$ derivative of LE392

$h s d R\left(\mathrm{r}^{-} \mathrm{m}^{+}\right)$recA pro $\mathrm{T} \mathrm{p}^{\mathrm{r}} \mathrm{Sm}^{\mathrm{r}}$,

chromosomally integrated RP4

derivative

Prototroph

nal' rif $^{\mathrm{r}}$ derivative of PP1-2

Prototroph, bile acid ${ }^{+}$

Prototroph, bile acid ${ }^{+}$

Tn5 mutant of RAL8, deoxycholate- .

Accumulates compound 2 from 1

Tn 5 mutant of RAL8, bile acid-

Accumulates compound 5 from 1

Prototroph, bile acid ${ }^{+}$

Prototroph, bile acid ${ }^{+}$
Source or reference

Maniatis et al. (1982)

This paper

Simon et al. (1983)

Wong \& Dunn (1974)

This paper

Leppik \& Sinden (1987)

Leppik (1989)

\} Leppik \& Sinden (1987)

*Abbreviations: nal, nalidixic acid; rif, rifampicin; Sm, streptomycin; Tp, trimethoprim.

\section{Table 2. Plasmids used}

\begin{tabular}{lc}
\multicolumn{1}{c}{ Plasmid* } & Size $(\mathbf{k b})$ \\
pSUP5011 & $12 \cdot 8$ \\
RP1 & 56 \\
pED709 & - \\
pMMB33 & $14 \cdot 1$ \\
pRAL3.21 & 53.4 \\
pRAL3.31 & $48 \cdot 4$ \\
pRAL3.35 & $44 \cdot 9$ \\
pRAL3.40 & $46 \cdot 1$
\end{tabular}

\section{Relevant characteristics $\dagger$}

$\mathrm{Cm}^{\mathrm{r}} \mathrm{Km}^{\mathrm{r}} \mathrm{Pp} \mathrm{p}^{\mathrm{r}}$, pBR325-based vector, containing Tn5-Mob

$\mathrm{Km}^{\mathrm{r}} \mathrm{Pp}^{\mathrm{r}} \mathrm{Tc}^{\mathrm{r}}$, IncP-1

$\mathrm{Km}^{\mathrm{s}}$ derivative of $\mathbf{R P}$

$\mathrm{Km}^{\mathrm{r}} \cos \lambda$

$\mathrm{Km}^{\mathrm{r}}$, primary plasmid from clone $8 \mathrm{~S} 46$

$\mathrm{Km}^{\mathrm{r}}$, primary plasmid from clone $8 \mathrm{Z} 30$

$\mathrm{Km}^{\mathrm{r}}$, primary plasmid from clone $8 \mathrm{AC} 20$

$\mathrm{Km}^{\mathrm{r}}$, primary plasmid from clone $8 \mathrm{P} 18$
Source or reference

Simon (1984)

Thomas (1981)

J. Pemberton

\}

This paper

* The DNA deletion plasmids derived from pRAL3.21 and pRAL3.40 are shown in Fig. 2.

† Abbreviations: Cm, chloramphenicol; Km, kanamycin; Pp, piperacillin; Tc, tetracyline.

Plate matings. Patch-mating between RAL8 and Escherichia coli S17.1 (pSUP5011) was done as previously described (Leppik \& Sinden, 1987). In the other matings, the recipient strain was spotted onto rich medium plates using a 48-pin replicator, the plates incubated at $30^{\circ} \mathrm{C}$ for $2-3 \mathrm{~h}$ till the spots were visible, then the donor clones replicated into the recipient spots. After a further 5-6 h incubation, the growths were replicated onto selective plates, as described in Results.

Purification and manipulation of DNA. Plasmid DNA was isolated by procedures based on the Brij lysis method of Clewell \& Helinski (1969), the small-scale boiling method of Holmes \& Quigley (1981), or the large plasmid isolation method of Hansen \& Olsen (1978). DNA digestions were done as described by Maniatis et al. (1982), and the DNA fragments were separated by electrophoresis in $0.6 \%$ or $1.5 \%(\mathrm{w} / \mathrm{v})$ agarose gels in TBE buffer (Maniatis et al., 1982), in a horizontal gel apparatus. The DNA size markers used were bacteriophage $\lambda$ DNA digested with either HindIII/KpnI (for $0.6 \%$ gels) or $H$ indIII $/ E c o$ RI (for $1.5 \%$ gels). Ligations with T4 DNA ligase were carried out as specified by the manufacturers.

Isolation of total DNA. An overnight culture in rich medium $(10 \mathrm{ml})$ was centrifuged $(3000 \mathrm{~g}, 5 \mathrm{~min})$, the pellet resuspended in lysozyme $\left(0.5 \mathrm{ml}, 10 \mathrm{mg} \mathrm{ml}^{-1}\right)$, then ribonuclease $\left(1 \mathrm{ml}, 2.5 \mathrm{mg} \mathrm{ml}^{-1}\right.$, previously incubated at $\left.80^{\circ} \mathrm{C}, 10 \mathrm{~min}\right)$, TE buffer $(0.5 \mathrm{ml} 10 \times$ concentrate; Maniatis et al., 1982) and water ( $3 \mathrm{ml})$ added. After $15 \mathrm{~min}$, SDS $\left(1 \mathrm{ml} \mathrm{20 \% ,w/v,} \mathrm{in} \mathrm{TE)} \mathrm{and} \mathrm{protease} \mathrm{type} \mathrm{XIV} \mathrm{(Sigma)}\left(1 \mathrm{ml} 2.5 \mathrm{mg} \mathrm{m}^{-1}\right.\right.$, previously incubated at $37^{\circ} \mathrm{C}$ for $2 \mathrm{~h}$ ) were added, and left at room temperature till clear. The lysate was extracted with phenol $(10 \mathrm{ml}$ then $5 \mathrm{ml})$, phenol/chloroform ( $1: 1, \mathrm{v} / \mathrm{v} ; 5 \mathrm{ml}$, containing $4 \%, \mathrm{v} / \mathrm{v}$, isoamyl alcohol), and chloroform ( $2 \times 5 \mathrm{ml}$, containing $4 \%$ isoamyl alcohol). Sodium acetate $(0.1 \mathrm{vol} ., 3 \mathrm{M})$ and ethanol $(2 \mathrm{vols})$ were added, and the mixture left at $-20^{\circ} \mathrm{C}$ for $1-2 \mathrm{~h}$. The mixture was centrifuged $(3000 \mathrm{~g}, 10 \mathrm{~min})$, the pellet washed with cold $70 \%(\mathrm{v} / \mathrm{v})$ ethanol $(5 \mathrm{ml})$, then dried under vacuum. The dried pellet was dissolved in TES buffer (10 ml; Maniatis et al., 1982), and dialysed against TE buffer. 
<smiles>CC(CCC(=O)O)C1CCC2C3CCC4C[C@@H](O)CCC4(C)C3CC(C)C12C</smiles><smiles>O=C1CCC2CCC3C(CCC45C=CC(=O)C4[C@@H](O)CC35)C12</smiles><smiles>O=C1CCC2C1C(O)C[C@H]1c3ccc(O)cc3CCC21</smiles><smiles>O=C1C=CC23C=CC(=O)CC24CC(O)C2C(=O)CCC2C4CCC3=C1</smiles>

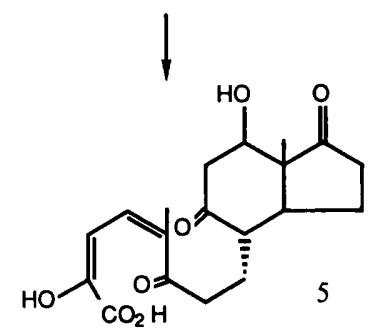<smiles>CCCCCC</smiles><smiles>O=C(O)CC[C@H]1[C@@H](O)CCC23CCC(=O)C12CC3</smiles>

Fig. 1. Abbreviated pathway for the degradation of deoxycholic acid by Gram-negative microorganisms. Compounds 1 to 6 are referred to in the text.

Cosmid cloning. Total DNA from RAL8 was partially digested with Sau3A, using the enzyme concentration which had been found in trial experiments to give the maximum number of fragments in the $25-50 \mathrm{~kb}$ range. The digested DNA was electrophoresed overnight at $4{ }^{\circ} \mathrm{C}$, in a $0.3 \%$ agarose gel which contained $1 \mu \mathrm{g}$ ethidium bromide $\mathrm{ml}^{-1}$. The DNA size markers used were a mixture of uncut $\lambda$ DNA (48.5 kb) and $\lambda$ DNA digested with $K p n I(29 \cdot 9,17 \cdot 1$ and $1.5 \mathrm{~kb}$ fragments). The approximately $25-50 \mathrm{~kb}$ DNA fragments were isolated from the gel, using the method of Dretzen et al. (1981).

The pMMB33 vector was digested as per method A of Frey et al. (1983), and then the sized DNA was ligated into the BamHI site of the cut vector. The methods of Priefer et al., (1984) were used for the preparation of $\lambda$ phage packaging extracts, for the packaging of the ligated DNA, then for the incorporation of this DNA into $E$. coli S17.1. S17.1 containing the DNA was plated onto rich medium plates containing kanamycin and grown at $30^{\circ} \mathrm{C}$; individual colonies were then transferred to fresh plates.

\section{RESULTS}

\section{Chromosomal location of the bile acid catabolic genes}

Tn 5 transposon mutagenesis has been performed in this laboratory with four phenotypically different Pseudomonas parent strains. The bile acid mutants isolated that have been characterized to date were found to accumulate either an androstane compound ( 2 or 3 ; Fig. 1), the secophenol (4) or the disecoandrostane (5) (Leppik \& Sinden, 1987; Leppik, 1989). In order to determine the cellular location of the bile acid catabolic genes in the four parent strains, it was first necessary to know whether any of the strains harboured plasmids. To answer this, the largeplasmid isolation method developed by Hansen \& Olsen (1978) was used. One of the parent strains, RAL8, contained one plasmid, but no plasmids could be detected in the other three parent strains, RAL1, RAL20 or RAL91 (Table 1). By comparison with known plasmids on gel electrophoresis, it was estimated that the size of the RAL8 plasmid was $45 \mathrm{~kb}$.

To determine whether the plasmid of RAL8 was necessary for bile acid degradation, it was desirable to first insert a suitable marker into the plasmid. An ideal marker is the transposon 
Tn5-Mob, as it not only encodes for kanamycin resistance, but also contains the 'Mob site' from the plasmid RP4 (Simon, 1984). The presence of the 'Mob site' should allow any non-selftransmissible plasmid to be mobilized once the transfer functions of RP4 (or RP1) are provided in trans (Simon, 1984). The Tn5-Mob transposon is contained in the pSUP5011 plasmid (Table 2), a narrow-host-range plasmid which can be mobilized into Pseudomonas strains, but which should not be able to replicate once within those strains (Simon, 1984).

E. coli S17.1 (pSUP5011) was patch-mated overnight with the prototrophic RAL8, and 240 transconjugants were obtained after plating onto minimal medium containing glucose and kanamycin. The transconjugants were screened both for self-transmissible and for non-selftransmissible plasmids containing the Tn5-Mob transposon inserted. For the former, the RAL8 $\left(\mathrm{Km}^{\mathrm{r}}\right.$ ) transconjugants were mated with $P$. putida RAL34 (a nal ${ }^{\mathrm{r}}$ rif $^{\mathrm{r}}$ derivative of PP1-2; Table 1), then plated onto rich medium containing kanamycin, naladixic acid, and rifampicin. The presence of both nalidixic acid and rifampicin was necessary, as RAL8 can produce clones resistant to either antibiotic alone at too high a frequency. To screen for non-self-transmissible plasmids, a triple mating between the RAL8 $\left(\mathrm{Km}^{\mathrm{r}}\right)$ clones, RAL34 and E. coli RAL3 (pED709) (pED709 is a $\mathrm{Km}^{\mathrm{s}}$ derivative of RP1; Table 2) was done; these bacteria were also plated onto rich medium containing kanamycin, nalidixic acid and rifampicin.

Four $(1.7 \%)$ of the RAL8 $\left(\mathrm{Km}^{\mathrm{r}}\right) \times$ RAL34 crosses were found to be positive, indicating that a self-transmissible plasmid containing Tn5-Mob had been transferred into RAL34. The presence of the pED709 plasmid produced no further positive crosses with RAL34. Use of the method of Hansen \& Olsen (1978) showed that RAL34 $\left(\mathrm{Km}^{\mathrm{r}}\right)$ transconjugants isolated from the four positive crosses each contained a plasmid of approximately $55 \mathrm{~kb}$, suggesting that the RAL8 plasmid ( $45 \mathrm{~kb}$ ), which contained the Tn5-Mob transposon $(7.3 \mathrm{~kb})$, had been mobilized into the RAL34 recipients. This was confirmed by comparison of the HindIII and XhoI digestion patterns of the RAL8 plasmid with those of the RAL34 $\left(\mathrm{Km}^{r}\right)$ transconjugant plasmids.

One of the RAL8 $\left(\mathrm{Km}^{\mathrm{r}}\right)$ clones which gave a positive cross with RAL34, and hence contains a pRAL8::Tn5-Mob plasmid, was subjected to mitomycin C curing, using the method of Chakrabarty et al. (1973). The highest concentration of mitomycin C which still allowed growth of the RAL $\left(\mathrm{Km}^{\mathrm{r}}\right)$ clone in Luria broth within $3 \mathrm{~d}$ was $5 \mu \mathrm{g} \mathrm{ml}^{-1}$, there being no growth after $4 \mathrm{~d}$ with $8 \mu \mathrm{g}$ mitomycin $\mathrm{C} \mathrm{ml}^{-1}$. The culture grown at $5 \mu \mathrm{g} \mathrm{ml}^{-1}$ was diluted and plated onto rich medium, then 240 of the colonies obtained after incubation were tested for growth on rich medium plates containing kanamycin. Fourteen $(6 \%)$ of the colonies were found to be $\mathrm{Km}^{\mathrm{s}}$. The 240 colonies were also tested for growth on minimal medium plates containing either glycodeoxycholate, taurodeoxycholate, cholate, deoxycholate, chenodeoxycholate or androsta-1,4-diene-3,17-dione. All of the colonies, including the 14 cured ones, grew on all the carbon sources tested, showing that the plasmid present in RAL8 was not necessary for growth on bile acids.

\section{Preparation and screening of an RAL8 gene bank}

From an examination of the proposed catabolic pathway (Leppik \& Sinden, 1987), it can be estimated that in excess of twenty enzymic reactions would be needed for the conversion of the bile acids as far as the indane acid (6) (Fig. 1). With a pathway of this size, clustering of genes into operons is a distinct possibility. It was thus desirable to isolate large chromosomal DNA segments, in order to maximize the probability of obtaining intact operons, if such exist for the pathway. Cosmid cloning is the cloning method of choice for this. The vector chosen was the $\mathrm{Km}^{\mathrm{r}}$, broad-host-range cosmid vector pMMB33 (Frey et al., 1983), as such a vector would allow the screening of the subsequent gene bank by mobilization into Pseudomonas mutant strains.

Whole cell DNA from RAL8 was partially digested with Sau3A, the DNA fragments of approximately $25-50 \mathrm{~kb}$ in length were isolated, then cloned into the BamHI site of pMMB33. The ligated DNA was packaged into $\lambda$ phage, then incorporated into $E$. coli $\mathrm{S} 17.1$. This strain was used as host strain as it is not only rec $A^{-}$, but also contains an RP4-2 derivative integrated into its chromosome (Simon et al., 1983). The latter would enable the resultant gene bank to be mobilized directly, without the prior addition of a mobilizing plasmid.

As a result of the cosmid cloning, a gene bank of $1700 \mathrm{Km}^{\mathrm{r}}$ clones was obtained. To screen this 
gene bank, two Pseudomonas mutant strains with a low frequency of reversion were chosen. The strains were RAL8.14, which accumulates the $12 \alpha$-hydroxyandrostane derivative (compound 2, Fig. 1) from deoxycholic acid (1) (Leppik \& Sinden, 1987), and RAL8.17, which accumulates the disecoandrostane derivative (5) (Leppik, 1989). The two mutant strains were mated with the gene bank clones on rich medium plates for $5 \mathrm{~h}$, then replicated onto minimal medium plates containing either deoxycholic acid (1) (RAL8.14 crosses) or androsta-1,4-diene-3,17-dione (RAL8.17 crosses). Four clones of the gene bank were found to give positive complementation with RAL8.14, and three of these four clones, but no others in the gene bank, to give a positive complementation with RAL8.17. This suggested that the two mutated genes are quite close to each other on the chromosome.

\section{Derivation of a restriction map for the cloned DNA}

The original colony obtained for one of the positive gene bank clones, 8S46, was streaked to obtain single colonies, and forty isolates were checked via complementation. Twenty-seven of the isolates complemented both RAL8.14 and RAL8.17, with the complementation ranging from good to poor, whilst the remaining thirteen isolates did not complement either mutant. Plasmids obtained from twenty of the isolates were digested with HindIII, and gel electrophoresis revealed ten different digestion patterns, with a total size per plasmid ranging from approximately 20 to $50 \mathrm{~kb}$.

To determne whether the extensive variation found was due to DNA deletions only, or whether DNA duplications and/or rearrangements had also occurred, 11 subclones of $8 \mathrm{~S} 46$ were chosen, each containing a plasmid with a different HindIII digestion pattern. The restriction sites for nine endonucleases were determined for each plasmid, and the resultant maps for eight of the enzymes are shown in Fig. 2; the ninth enzyme, HpaI, had only the one site present in the vector. The maps were found to be identical in their regions of overlap, and no evidence of DNA duplication or rearrangement could be seen.

One of the 11 plasmids mapped, pRAL3.21, appeared to be the original plasmid of 8S46. It contained all of the partial sequences of the other ten plasmids examined, and was $53.4 \mathrm{~kb}$ long, at the upper limit of the size that can be packaged into a $\lambda$ phage head. The cloned DNA contained in pRAL3.21 was $39.4 \mathrm{~kb}$ long. The maps of the other ten plasmids showed quite variable DNA deletions, which even extended into the vector in four cases (Fig. 2).

The other two gene bank clones which complemented both RAL8.14 and RAL8.17, 8Z30 and $8 \mathrm{AC} 20$, were then examined, and both were also found to have unstable plasmids. However, subclones of each could be isolated that gave a positive complementation with the above two mutants, and which also appeared to contain the original plasmids of the two clones. The restriction endonuclease sites were mapped, and comparison of the mapping patterns of these plasmids, and that of pRAL3.21, showed complete agreement in their regions of overlap (Fig. 2). The $8 Z 30$ plasmid, pRAL3.31 (48.4 kb), and the 8AC20 plasmid, pRAL3.35 $(44.9 \mathrm{~kb})$, commence only $1.1 \mathrm{~kb}$ apart on the map, but pRAL3.35 has the shorter insert, $30.8 \mathrm{~kb}$, as against $34.3 \mathrm{~kb}$ for pRAL3.31 (Fig. 2). The pRAL3.35 insert is also in the opposite orientation in the vector, compared to that found for pRAL3.21, pRAL3.31 and pRAL3.40 (see below).

The final gene bank clone, 8P18, which complemented RAL8.14 but not RAL8.17, was found to contain the most unstable plasmid of the four clones. The majority of the $\mathrm{Km}^{\mathrm{r}}$ subclones isolated from it contained plasmids smaller than $23 \mathrm{~kb}$. Some of the restriction sites on twelve of these plasmids were mapped, and eight were found to have deletions extending into the vector. The mapping patterns obtained agreed with the restriction map derived above, in the regions of overlap.

Unstable subclones of $8 \mathrm{P} 18$ were obtained, however, which appeared to contain the original plasmid. If correct, then restriction digests show that the original 8P18 plasmid, pRAL3.40, is approximately $46.1 \mathrm{~kb}$ long, with an insert of approximately $32.0 \mathrm{~kb}$. This plasmid has not been fully mapped, but the mapping pattern found at the right-hand end does not correspond to any other part of the map of Fig. 2. Thus, if the cloned DNA was originally obtained from an undetected RAL8 plasmid, then that plasmid would have to be larger than $68 \mathrm{~kb}$.

Complementation tests were done on all of the above subclones, and RAL8.14 and RAL8.17. 


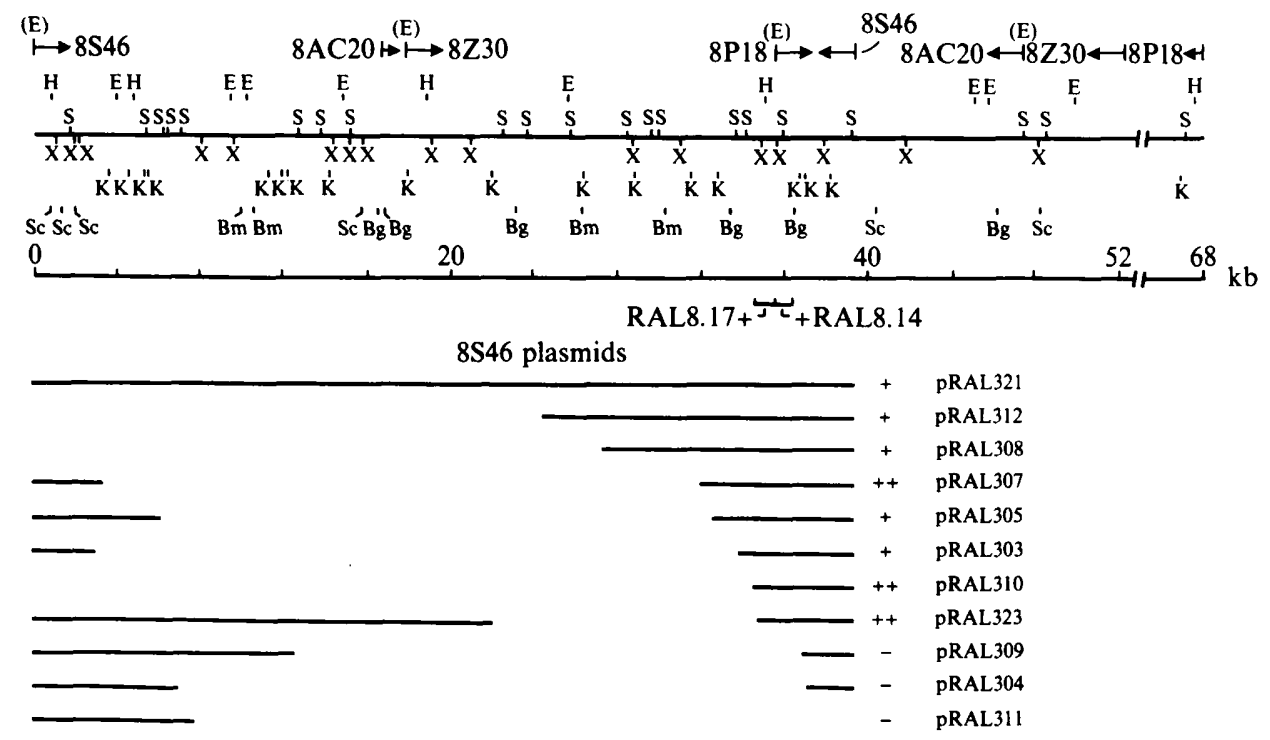

$8 \mathrm{P} 18$ plasmids

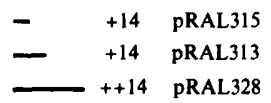

Fig. 2. Restriction map of the chromosomal DNA contained by the gene bank plasmids which complement the bile acid mutants RAL8.14 and RAL8.17, together with deletion maps of plasmids derived from 8S46 and 8P18. - chromosomal DNA. Symbols used: $++/+$, good/reasonable complementation, both mutants; $++14 /+14$, good/reasonable complementation, RAL8.14 only; - , no complementation, either mutant; + RAL8.14, DNA region needed for RAL8.14 complementation; RAL8.17+, DNA region needed for RAL8.17 complementation. Enzymes used: Bm, BamHI; Bg, BglII; E, EcoRI; (E), vector EcoRI site; H, HindIII; K, KpnI; S, SmaI; Sc, SacI; X, XhoI.

From the results (Fig. 2), it is seen that the maximum DNA needed for complementation of RAL8.14 is the $0.8 \mathrm{~kb}$ segment between 35.7 and $36.5 \mathrm{~kb}$. Similarly, the maximum DNA needed for complementation of RAL8.17 is the $1.1 \mathrm{~kb}$ region between 34.6 and $35.7 \mathrm{~kb}$ (Fig. 2).

\section{DISCUSSION}

Bile acid degradation by Pseudomonas sp. RAL8 has been investigated over a number of years in this laboratory, first in the wild-type organism (Leppik, 1980, 1983), and more recently in Tn5 transposon mutants (Leppik \& Sinden, 1987; Leppik 1989). This has resulted in the derivation of a bile acid catabolic pathway, which would appear to be generally applicable to Gramnegative micro-organisms.

The studies on RAL8 have now been extended into the genetic area. As a prelude to such studies, it was first necessary to establish the location of the bile acid catabolic genes. Strain RAL8 was found to have at least one plasmid which, after labelling with the transposon Tn5Mob, was shown to be capable of self-mobilization into $P$. putida RAL34. However, curing studies showed that this plasmid was not necessary for bile acid catabolism, suggesting that the genetic information for the entire pathway is chromosomally located in strain RAL8. The three other strains used in the Tn5 mutagenesis studies were examined. The absence of plasmids indicated that the pathway is also chromosomally encoded in these strains.

Because of the length of the bile acid pathway, cosmid cloning was utilized, in order to maximize the probability of isolating intact operons, if such exists for the bile acid pathway. A gene bank of 1700 clones was generated from RAL8 chromosomal DNA, using the broad-hostrange vector pMMB33 (Frey et al., 1983). The gene bank was screened against two mutants of 
RAL8, which were blocked in the utilization of compounds (2) and (5) respectively. Four of the gene bank clones complemented the first mutant, and three of these four clones, but no others, complemented the second mutant. It would thus appear that the two genes mutated lie close to each other on the chromosome.

Examination of the four positive gene bank clones revealed that the plasmids formed initially were unstable. More stable subclones could, however, be isolated, and detailed mapping of the plasmids in these subclones showed extensive and variable DNA deletions from the initial plasmids, including deletions extending into the vector in a number of cases. However, no evidence was found for either DNA rearrangements or DNA duplications. Consequently, a restriction map for eight endonucleases could be derived, covering $52.2 \mathrm{~kb}$ of the chromosome (Fig. 2).

Complementation studies between the various subclones obtained and the two RAL8 mutants enabled the map positions for the DNA necessary for complementation to be located (Fig. 2). Thus, it would appear that the point of $\operatorname{Tn} 5$ insertion which results in the accumulation of the $12 \alpha$-hydroxyandrostane compound (2) lies between 35.7 and $36.5 \mathrm{~kb}$ on the map, and the Tn 5 insertion point resulting in the accumulation of the disecoandrostane derivative (5) lies between 34.6 and $35.7 \mathrm{~kb}$. The closeness of the two genes mutated is compatible with the presence of an operon, a possibility which is also supported by the results of the Tn 5 mutagenesis work (Leppik \& Sinden, 1987). Further studies to confirm such a possibility are now underway.

The work presented in this paper will provide a firm foundation to further investigations into the genetics of bile acid catabolism. Such studies could, in turn, enable the production of stable Pseudomonas strains tailored to produce commercially important intermediates in high yield.

I wish to thank Professor K. N. Timmis for the opportunity to spend a period of time in his laboratories, and Drs P. Lehrbach and G. Boulnois for their invaluable guidance whilst I was learning techniques for the manipulation of DNA. The technical assistance of Miss G. Thompson is also acknowledged.

\section{REFERENCES}

Chakrabarty, A. M., Chou, G. \& Gunsalus, I. C. (1973). Genetic regulation of octane dissimilation plasmid in Pseudomonas. Proceedings of the National Academy of Sciences of the United States of America 70, 1137-1140.

Clewell, D. B. \& HelinsKi, D. R. (1969). Supercoiled circular DNA-protein complex in Eschericia coli: purification and induced conversion to an open circular DNA form. Proceedings of the National Academy of Sciences of the United States of America 62, 1159-1166.

Coleman, J. P., White, W. B. \& Hylemon, P. B. (1987). Molecular cloning of bile acid 7-dehydroxylase from Eubacterium sp. strain VP1 12708. Journal of Bacteriology 169, 1516-1521.

Dretzen, G., Bellard, M., Sassone-Corsi, P. \& Chambon, P. (1981). A reliable method for the recovery of DNA fragments from agarose and acrylamide gels. Analytical Biochemistry 112, 295298.

Frey, J., Bagdasarian, M., Feiss, D., Franklin, C. H. \& Deshusses, J. (1983). Stable cosmid vectors that enable the introduction of cloned fragments into a wide range of Gram-negative bacteria. Gene 24 , 299-308.

HANSEN, J. B. \& OLSEN, R. H. (1978). Isolation of large bacterial plasmids and characterization of the P2 incompatibility group plasmids pMG1 and pMG5. Journal of Bacteriology 135, 227-238.

Holmes, D. S. \& QuigleY, M. (1981). A rapid boiling method for the preparation of bacterial plasmids. Analytical Biochemistry 114, 193-197.
IDE, J. A., PARK, R. J. \& DunN, N. W. (1986). Bile acid catabolites accumulated by transposon-induced mutants of Pseudomonas putida: production of hydroxylated 1,4-androstadiene-3,17-diones. Biotechnology Letters 8, 763-768.

LEPPIK, R. A. (1980). Degradation of deoxycholic acid by a Pseudomonas sp. Proceedings of the Sixth International Fermentation Symposium, London, Canada. Advances in Biotechnology 3, 489-494.

LEPPIK, R. A. (1983). Deoxycholic acid degradation by a Pseudomonas sp.: acidic intermediates with A-ring unsaturation. Biochemical Journal 210, 829-836.

LePpik, R. A. \& Sinden, D. J. (1987). Pseudomonas mutant strains that accumulate androstane and secoandrostane intermediates from bile acids. Biochemical Journal 2A3, 15-21.

LEPPIK, R. A. (1989). Steroid catechol degradation: disecoandrostane intermediates accumulated by Pseudomonas transposon mutant strains. Journal of General Microbiology 135, 1979-1988.

Maniatis, T., Fritsch, E. F. \& SAMbroOK, J. (1982). Molecular Cloning: a Laboratory Manual. Cold Spring Harbour, NY: Cold Spring Harbour Laboratory.

PARK, R. J., DunN, N. W. \& IDE, J. A. (1988). A catecholic 9,10-secosteroid as a product of aerobic catabolism of cholic acid by a Pseudomonas sp. Steroids 48, 439-450.

Priefer, U., Simon, R. \& PuHLer, A. (1984). Cloning with cosmids. In Advanced Molecular Genetics, pp. 190-201. Edited by A. Puhler \& K. N. Timmis. Berlin: Springer-Verlag. 
SimoN, R. (1984). High frequency mobilisation of Gram-negative bacterial replicons by the in vitro constructed Tn5-Mob transposon. Molecular and General Genetics 196, 413-420.

Simon, R., Priefer, U. \& PUHLeR, A. (1983). A broad host range mobilisation system for in vivo genetic engineering: transposon mutagenesis in Gram negative bacteria. Bio/Technology 1, 784-791.

Tenneson, M. E., Bilton, R. F., Drasar, B. S. \&
Mason, A. N. (1979). The possible role of catabolic plasmids in bacterial steroid degradation. FEBS Letters 102, 311-315.

ThOMAS, C. M. (1981). Molecular genetics of broad host range plasmid RK2. Plasmid 5, 10-19.

Wong, C. L. \& DunN, N. W. (1974). Transmissible plasmid coding for the degradation of benzoate and $\mathrm{m}$-toluate in Pseudomonas arvilla $\mathrm{mt}-2$. Genetical Research 23, 227-232. 